\title{
Negative Double Jeopardy: The role of anti-brand sites on the internet
}

Received (in revised form): 2nd May, 2007

\section{S. UMIT KUCUK}

is currently teaching various marketing courses at the University of Washington, Bothell and was recently a postdoctoral fellow at the Darden Graduate School of Business Administration, University of Virginia. His work appears in the International Journal of Retail \& Distribution Management, Journal of Euro-Marketing, Journal of International Consumer Marketing and the Technovation.

\section{Keywords}

anti-consumption;

anti-branding; branding; brand identity; double jeopardy; search engine; marketing
S. Umit Kucuk

Business Administration Program, University of Washington, Bothell, Box 358533, I8I I 5 Campus Way NE, Bothell,WA 980II-8246, USA Fax: + I 4253525277

E-mail: ukucuk@uwb.edu or umit.kucuk@gmail.com

\section{Abstract}

This study discusses the role of anti-brand websites and their importance in markets within a new conceptualisation-Negative Double Jeopardy (NDJ): 'the most valuable brands attract more anti-brand sites while less valuable brands do not have such hate attraction on the Internet'. In this context, the forms and reasons of anti-brand sites are investigated in light of this newly proposed NDJ phenomenon. NDJ components are identified as 'Brand Rank' and 'Brand Consistency'. Typology of anti-brand sites with regard to NDJ is also studied and finally managerial implications are addressed.

Journal of Brand Management (2008) 15, 209-222. doi:10.1057/palgrave.bm.2550100; published online 8 June 2007

\section{INTRODUCTION}

The 'Double Jeopardy (DJ)' phenomenon in marketing theory illustrates that strong brands have multiple advantages over weak brands, for example, strong brands may have more customers, higher penetration and also a higher degree of brand loyalty leading to high repeat purchases. ${ }^{1,2}$ Notably, the DJ effects have repeatedly shown that this DJ or multiple jeopardy is manifested in many different product categories ${ }^{1}$ and in consumers' store selection decisions as well. ${ }^{3}$ Recently, researchers have also shown that DJ effects are visible on the internet, locating these effects with search engines and online book/music retailers. ${ }^{4}$ The top search engines show higher frequency of usage, consumer intentions to use the site in the future and time spent on the internet. Leading online book/music retailers were also shown to have similar advantages.

On the other hand, strong brands also have multiple disadvantages over weaker brands. Brand strength is affected positively by advantages but negatively by disadvantages, such as varying forms of anti-brand and anti-consumption activity. Today, many anti-brand and anti-consumption movements focus their efforts and energy into anti-brand hate sites. The most valuable brands (high in ranking and consistently listed on Business Week's 'Top 100 Brands' List-BW List) may attract more anti-brand hate site attention than less valuable brands. In other words, companies may experience effects similar to those of DJ, but in an opposite direction in the form of hate site targeting on the internet. We, therefore, will conceptualise this new phenomenon and brand effect on the internet as 'Negative Double Jeopardy (NDJ)' inspired by the wellknown DJ phenomenon in marketing theory.

In this paper, this new NDJ concept will be discussed with regards to anti-brand-or hate — sites to devise management strategies 
in order to minimise the negative impacts of anti-branding efforts on the internet and to reach more effective and productive market relationships. The paper is structured as follows: first, the role and form of anti-brand sites and NDJ effects in the markets are discussed, and then components of NDJ are defined as brand rank and consistency in BW List and tested with available data. Later, a typology of anti-brand sites is developed, and the perspective of each anti-brand site is discussed individually to understand the difference in such sites to be able to develop strategies to handle such NDJ effects. Finally, managerial implications are proposed in the light of ongoing discussions.

\section{THE ROLE OF ANTI-BRAND SITES AND NDJ EFFECTS}

'The biggest digital risk problem keeping some senior executives awake at night is not hacking, viruses or network intrusion but corporate hate sites according to the oneto-one private interviews carried out with over 125 CEOs and CFOs of major global brands in North America, South America, Europe and Asia by the mi2g Intelligence Unit between December 2003 and November 2004. There are currently over 10,500 hate sites against major global brands on the Internet. This compares to 1,900 hate sites at the end of 2000, 550 hate sites at the end of 1997, and just one hate site in 1995'. mi2g Intelligence Unit ${ }^{5}$

Anti-brand websites are today's new form of boycott and protest, developed through consumer activism as a result of increasing consumer power with the advent of the internet. Consumers are able to clearly broadcast their messages and organise with other like-minded consumers, and to start using anti-brand websites as weapons of empowerment to battle the corporate world and its brand power on a day-to-day basis. ${ }^{6}$

One of the major reasons behind rising brand opposition movements on the internet is the internet's technological structure itself (all nodes are equal in status on the internet's nonhierarchical distributed network system), which can be conceptualised as providing 'speech equality', allowing for many-to-many communication rather than traditional one-to-many mass communication perspectives. In other words, consumers are no longer passive recipients of company information and advertising messages, but actively co-create market value. ${ }^{7}$ Put simply, the corporation has a website and so does the consumer. Because of this enhanced form of speech equality between the corporation and individual consumer on the internet, we are witnessing a new extreme form of expressed dissatisfaction: 'anti-brand hate sites'. This dissatisfaction is not just with a specific transaction or complaint; it goes beyond ordinary consumer complaint behaviours and addresses a wide range of issues. In conclusion, the internet - a most promising and revolutionary direct marketing tool—also empowers consumer activist groups by allowing them to broadcast their message at a very low cost to a vast audience on hate sites.

Such sites are attacking targeted brands and corporations by using their most powerful online branding tool against them: 'domain names'. Many such anti-brand domain names are easy to remember and catchy in nature (such as Northwest Airlines' Northworstair. org, Safeway's Shameway.com, Starbucks' Starbucked.com, Coca-Cola's Killercoke. org, etc). Anti-brand sites purposefully use the targeted corporation's brand name in their domain name to insult the corporation's brand identity and to express their 
anger and frustration while entertaining and educating consumers and audiences. For example, the founder of Walmartblows.com describes his motivation as follows:

'Pissed off at Wal-Mart, I needed a constructive way of releasing my frustration, so I bought a silly domain name and designed a Web site dedicated to my anger. I have created this site in retaliation against Wal-Mart for their crappy customer service and for treating their employees like $s-t$ '.

Many court decisions concluded that usage of a targeted brand's name in a domain name is not trademark infringement, but is protected under the First Amendment - as long as the site owner does not use the anti-brand site to make a profit. ${ }^{9,10}$ With these domain names, anti-brand sites are also benefitting by sharing the link popularity, brand awareness and web traffic of the targeted brands' site in many search engine results and in consumer surfing decisions on the internet. Anti-brand sites sometimes show up in the top ten search results when a corporate brand is searched on major search engines. Other sites are also taking advantage of mistyping (called typosquatting) to steal traffic directed to the targeted brand as in the case of Untied. com, a hate site targeting United Airlines (United.com).

For these oppositional consumer groups, anti-brand sites have turned out to be major message dissemination venues and a powerful communication tool. Today, hate sites exchange information, organise boycotts and coordinate lawsuits, thus revolutionising consumer movements against targeted brands on the internet. Many of the anti-brand sites function beyond ordinary complaint sites (such as e-complaints), and cover a wide range of issues-not only dissatisfaction caused by a simple transaction or service failures. Many of these sites are shown in the form of consumer revenge sites (aolsuck.com and starbucked.com-discussing inconsistent services and greedy business philosophies), disgruntled current and exemployee sites (walmart-blows.com-if a site discusses company policies and invites other employees to comment, then it can be considered 'concerted activity' and is protected by the National Labor Relations Act-NLRA), political basis websites (homedepotsuck.com and McSpotlight. com-harming the environment by destroying rainforests and using harmful packaging, corrupting the culture, monopolistic and anti-labour market practices) and competitor-supported anti-brand sites (Amway alleged that $P \& G$ has been a behind-the-scenes sponsor of a rogue website that foments hate rhetoric about Amway—suit filed in Michigan in $\left.1998^{11}\right)$.

All of the above forms of anti-brand hate sites directly and indirectly impact consumers' perceptions of the targeted brand's identity and image, consumer purchase decisions and might eventually affect companies' market share. Companies' brand value can also be used as a major market share indicators. Therefore, companies' placement or rank on the BW List and how long they stay on this list can also be used as an indicator of how well they are doing in the markets. In this context, NDJ components from the BW list can be used to indicate 'Brand Rank'; and 'Brand Consistency', indicating how long a specific brand is ranked in the list during the last five years. These two dimensions can also be used to show how much hate these brands are generating. This new form of anti-brand movement, and thus NDJ effects, should be investigated in terms of the aforementioned components in detail. 


\section{Method}

In order to understand the nature of the impact of these anti-brand sites on targeted brands, data were collected by using major search engines to determine the number of anti-brand websites for the brands listed in BW List ${ }^{12}$ between 1st May and 15th May, 2005. For each brand, hate sites were searched by using a set of negative terms, such as 'hate', 'anti', 'watch', 'blows', etc. The search was first conducted by using the brand name and a negative term, and then the same search was conducted using the brand and negative term together in quotation marks (eg Starbucks sucks and 'Starbucks sucks'). Each site was visited to make sure that each was an individual, unique site, as opposed to simply redirecting the consumer to another established site. If one site was just a conduit to another site, both sites were counted together as one. Sites were also used that were covered in media accounts. ${ }^{8}$ The distinction between web pages and sites was considered, and thus single posts to blogs or discussion boards were not included to this study, nor were Usenet groups (eg alt.microsoft.sucks, alt.destroy. microsoft).

First, the numbers of anti-brand sites attracted by the brands in the list are grouped in terms of NDJ components. The NDJ effects created by these sites can be clearly seen in Table 1 . The results indicated when high 'Brand Rank' within BW's list aligned with high 'Brand List Consistency' or 'Brand Consistency' an increase in hate sites can be seen. The research showed that when both components-Brand Rank and Brand Consistency - are present, the brand is more likely to attract the attention of consumer activists who then develop hate sites.

The data also reveals that being listed consistently in the BW List rather than being highly ranked is one of the major
Table I Negative double jeopardy effect in top 100 brand list

\begin{tabular}{|c|c|c|}
\hline \multirow[b]{2}{*}{$\begin{array}{l}\text { Brand } \\
\text { consistency** }\end{array}$} & \multicolumn{2}{|l|}{ Brand rank* } \\
\hline & High & Low \\
\hline \multirow[t]{2}{*}{ High } & I & 2 \\
\hline & $\begin{array}{l}24 \text { Brands (8I } \\
\text { anti-brand sites) }\end{array}$ & $\begin{array}{l}\text { I } 4 \text { Brands (42 } \\
\text { anti-brand sites) }\end{array}$ \\
\hline \multirow[t]{2}{*}{ Low } & 3 & 4 \\
\hline & $\begin{array}{l}4 \text { Brands (7 } \\
\text { anti-brand sites) }\end{array}$ & $\begin{array}{l}3 \text { Brands (4 } \\
\text { anti-brand sites) }\end{array}$ \\
\hline
\end{tabular}

* If brand is ranked in the first 50 , it is labelled High Brand Rank; otherwise it is Low Brand Rank.

** If brand is ranked more than three years, it is labelled High Brand Consistency; otherwise it is designated Low Brand Consistency.

Bold indicates how many brands targeted by antibrand site.

reasons behind the presence of anti-brand sites (14 brands and 42 anti-brand sites in cell-2 over four brands seven anti-brand sites in cell-3). Also, in cell-1 Table 1, 24 brands generate 81 anti-brand sites with an average of four anti-brand sites per brand; in cell-2 average about four antibrand sites; in cell average about two antibrand sites and finally in cell-4 average one anti-brand sites produced by each brands. Therefore, brand consistency plays a major role in attracting anti-brand sites, and such brands should be extra careful and conscious of being targeted by the anti-brand sites on the internet.

Secondly, although NDJ effects were observable in terms of anti-brand site frequencies in Table 1, binary logistic models are also developed to test the NDJ effects on the presence of anti-brand sites as depicted in Table 2.

Our data and variables are coded as follows: if a specific brand has an antibrand site, it is coded 1; if it does not, it is coded 0 (zero) in order to measure the anti-brand site presence. Brand Ranks are calculated by dividing the ranking into 
Table 2 Logistic regression results

\begin{tabular}{|c|c|c|c|c|c|}
\hline \multirow{3}{*}{$\begin{array}{l}\text { Dependent } \\
\text { Independents }\end{array}$} & \multicolumn{2}{|l|}{ Model-I } & \multirow{3}{*}{$\begin{array}{l}\text { Dependent } \\
\text { Independents }\end{array}$} & \multicolumn{2}{|l|}{ Model-2 } \\
\hline & \multicolumn{2}{|c|}{ Presence of anti-brand site } & & \multicolumn{2}{|c|}{ Presence of anti-brand site } \\
\hline & Coefficient & Odds & & Coefficient & Odds \\
\hline \multirow[t]{2}{*}{ NDJ } & $0.088^{*}$ & 1.091 & NDJ & $0.074 * *$ & 1.076 \\
\hline & & & DD & $0.829 * *$ & 2.290 \\
\hline$\chi^{2}$ & $6.912 *$ & & $\chi^{2}$ & $10.734^{*}$ & \\
\hline
\end{tabular}

four groups from BW's most valuable global brands list ('4' first 25th ' 3 ' second 25th, etc), and Brand Consistency represents how many times a specific brand was on the most valuable global brand list in the last five years (' 1 ' if it is listed one year, ' 5 ' if it is listed every year). NDJ values, as a result, are calculated as (Brand Rank $) \times($ Brand Consistency). In order to understand the NDJ effects on a company's likelihood of having an anti-brand site, we used the most appropriate model for our data: the binary logistic regression model.

In model 1, NDJ effects are statistically significant. In other words, it is likely that NDJ effects are related to Brand Rank and Consistency, which can be associated with corporations' anti-brand site presence in the markets.

Although NDJ effects can be observed in the US, this might not be the case in other countries (if, eg the consumers in a different country might not be as internetsavvy as American consumers). Since there are some international brands in BW List, this factor needed extra attention as well. The lack of anti-brand sites might be caused by information technology infrastructure problems, language and cultural differences ${ }^{13}$ and is conceptualised as the 'Digital Divide (DD)' in e-commerce literature. American consumers are more connected and aware of the pros and cons of their actions and internet marketing, thus it might be more common to see these anti-brand sites' having an impact on US brands than on other international brands. Another possible reason could be Americans' love-hate relationship with brands. ${ }^{14}$ Americans might love their brands more than Europeans and that might be the reason behind increasing hate sites in the US. Simply, observation of NDJ effects on such international brands and markets might be limited to the date. Therefore, in order to observe NDJ effects we built another model (model-2 in Table 2) taking account of the DD phenomena to test the anti-brand site presence in the markets.

If the specific brand is a US brand, it is coded 1 ; if it is international brand, it is coded 0 (zero) in order to take account of DD effects. Even when DD is included in the model, NDJ effects continue to be statistically significant.

Overall, the study's results showed clear NDJ effects - that the most valuable brands are targeted by anti-brand sites (sometimes multiple sites), while less valuable brands have no hate sites. The impacts and perspectives of such sites are, however, still unknown and the question remains: 'How are each group of anti-brand sites that cause NDJ effects making their points to influence potential consumers and markets?' In order to answer this question, a typology is developed to understand each site's objectives. 


\section{Typology of anti-brand sites with regard to NDJ matrix}

Hirschman's ${ }^{15}$ well-known 'Exit-Voice' theory draws attention to a missing link in the market mechanism: 'consumers' respond to companies and markets with not just product/brand choice decisionsexit; refuse to consume, brand switching, change in purchase frequency-but also actively giving voice to consumer concerns'-voice; complaints, consumer activism...'. In other words, consumers can be neither totally alienated nor liberated from brands and markets. ${ }^{16}$ Instead, they create alternative meanings and social codes regarding such brands in the markets, which can be defined as 'liberatory postmodernism', ${ }^{17}$ —in order to differentiate themselves from consumption cycles of the company-created consumption system. ${ }^{18} \mathrm{~W}$ ith the internet, consumer liberation from, and transformation of, symbolic meanings in the markets-which are mainly represented by brands-are much easier and the consumer is now able to make his/ her disdain for these corporate-created meanings known.

In this context, the reasons behind the propensity of some brands to generate more anti-brand sites than others, and the common points shared by such antibrand sites in creating pressure on corporations' brand identity should be discussed in detail. For this purpose, all of the anti-brand sites were analysed in order to understand their counterarguments and major points of view; as well as web content quality and visual expressiveness. And finally, a new anti-brand sites typology is developed with regard to the NDJ concept as also depicted in Table 3.

The following sections are organised to provide evidence of the conceptual classification of such anti-brand sites.
Table 3 Typology of anti-brand sites with regard to the NDJ matrix

\begin{tabular}{lll}
\hline & Brand rank \\
\cline { 2 - 3 } $\begin{array}{l}\text { Brand } \\
\text { consistency }\end{array}$ & High & Low \\
\hline High & Experts & $\begin{array}{l}\text { Symbolic } \\
\text { Haters }\end{array}$ \\
Low & Complainers & Opportunists \\
\hline
\end{tabular}

\section{Experts (high brand rank, high brand consistency)}

The developers of these sites have broader knowledge about markets and alternatives, and expertise about business practices, products and technologies. Because of their advanced level of expertise, they are capable of sensing and following market changes in real time (eg killercoke.org announces the news about Coca-Cola on a daily basis from many reliable sources such as Associated Press, etc), and developing counter-strategies against perceived business malpractices. Walmart-blows.com provides membership for visitors who want to login to discussion groups and learn more about employment discrimination issues and educate their followers.

Generally these sites discuss issues in an analytical way supported by important market information. Experts generally oppose the consumption culture and system created by such companies. For example, although one consumer explains that he is neither a vegetarian nor an extremist animal rights supporter, he writes a passionate explanation of why he refuses to patronise McDonalds. He raises issues such as rain forest destruction and erosion resulting from the beef industry's practice of clear-cutting in order to graze cattle. He concludes with the warning:'for every pound of beef you eat, 55 acres of rainforest were destroyed'. ${ }^{19}$ This consumer analyses the company's operations and is 
protesting the company because of its production style and not simply product or service failures or consumption-related issues. Although the consumer in this example might actually enjoy this company's products and clearly differentiates himself from other protest groups (ie vegetarians and animal activists), he/she understands and disapproves of the company's production process. Some such sites give extensive and detailed information citing to actual documents that reveal what is wrong with the targeted brand from their point of view. ${ }^{20}$ Others provide links to thought-provoking experts and authors regarding the issues, ${ }^{21}$ to alternative products (eg Ihatemicrosoft.com links to visitors to free open source software), and to related anti-brand and boycott sites to organise a collective movement to disseminate their messages to public. $^{22}$ This, in effect, creates some level of economic pressure by stimulating anti-consumption against the targeted brands. Overall, the arguments raised by such sites are more constructive, well articulated and directly question the company's existence.

Many experts set out to become their own media source instead of expecting support from the general media. Their websites show advanced design techniques and communication skills, potentially developing themselves as an independent media outlet. Some sites welcome visitors with an interactive talking 'host' with very easy-to-use features (the person on the front page display says: 'click on me for more information', as in Ihatemicrosoft.com). Some experts apply strong expressiveness and communication strategies with unforgettably powerful images to maximise their impact on visitors to the site and the markets with the ultimate purpose of creating brand identity erosion (see Figure 1 for examples).

\section{Symbolic haters (low brand rank, high brand consistency)}

The brands targeted by symbolic haters have high brand awareness in the markets and are ranked consistently on the BW List, but generally appear low on the list. They are not as valuable as those targeted by the experts. The more popular these brands become, the louder and more comprehensive, however, the hate towards the targeted company might be.

This group of anti-brand protesters is sustained predominantly by negative WOM (word of mouth) or rumour in the markets, and focus more on the myths behind the brand's success (or what people are saying about them-what's 'hot') and put those issues in the centre of their negative speech. Since the brands they target are consistently ranked, these symbolic haters might have a better chance of attracting more public attention to the issues they promote. For example, amazon.com created a one-click purchasing process to improve its customer service by making it easy for a consumer to make an online purchase by saving the customer's information from a previous transaction. Some consumers no doubt appreciate this change and see it as an improvement. Symbolic haters, however, may view Amazon's 'improvement' with suspicion, believing that Amazon is attempting to steal consumers' financial information for its own impermissible purposes.A symbolic hater's arguments against a company are largely based upon suspicion and rumour, as opposed to the factual business malpractice evidence relied upon by experts. ${ }^{23,24}$ Another example would be protestors who hate Starbucks because it might be currently perceived as fashionable to hate that specific corporation that has achieved such widespread availability. The symbolic hater adopts this 'hate' of the company because of social pressure to support coffee 


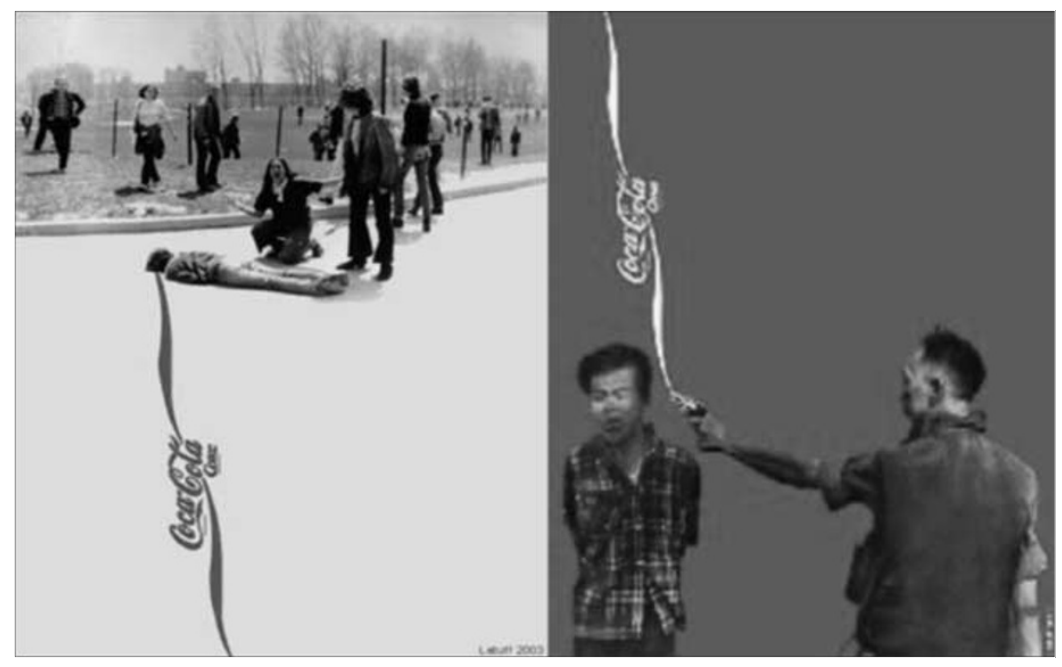

Figure I Examples of the visual expressiveness of experts, http://www.frot.co.nz/wheels/coca-cola.htm visited on 27th July, 2006

shops that might offer a more unique experience.

Here are the comments of the founder of a hate site dedicated to Starbucks;

'Personally, I hate them because their coffee sucks and they are everywhere. You can't escape them'. ${ }^{25}$

The founder of this site makes general arguments without providing any technical or market information. The point made here is rather relative, related to personal taste and is not as convincing and trustworthy as the arguments put forth by experts. This site may also be repeating and imitating the points of view that have been articulated by others because it is popular and fun to do so.

Their expressiveness and web design are not as sophisticated as those of the experts, and may rely more on humour than other groups of protestors. Here, the protestors changed the company's brand symbol by adding horns to indicate evil and added a cross sign over the targeted brand's symbols (starbucked.com, etc); some others also included a cartoon to entertain consumers about their major arguments as seen in examples in Figure 2.

\section{Complainers (high brand rank, low brand consistency)}

Complainers target brands that have not been ranked in the list previously, and that debut in the top 50 companies (but generally closer to the top ten or 20). Complainers reflect their anger by bringing negative attention to the company with service failure scandals in order to create opposition to the targeted brands. They are more interested in operational and product-related problems than business philosophy or system order. They might have initially tried to build communication with the company regarding their concerns, but their insight was not appreciated by the company, and they chose to protest them on hate sites using 'wake-up call'-type attention grabbers to get their point across (eg UPS smashed or undelivered packages ${ }^{26-29}$ and Citibank hidden fees, service inconveniences failures $\left.{ }^{30}\right)$. Some such sites even give hints to 


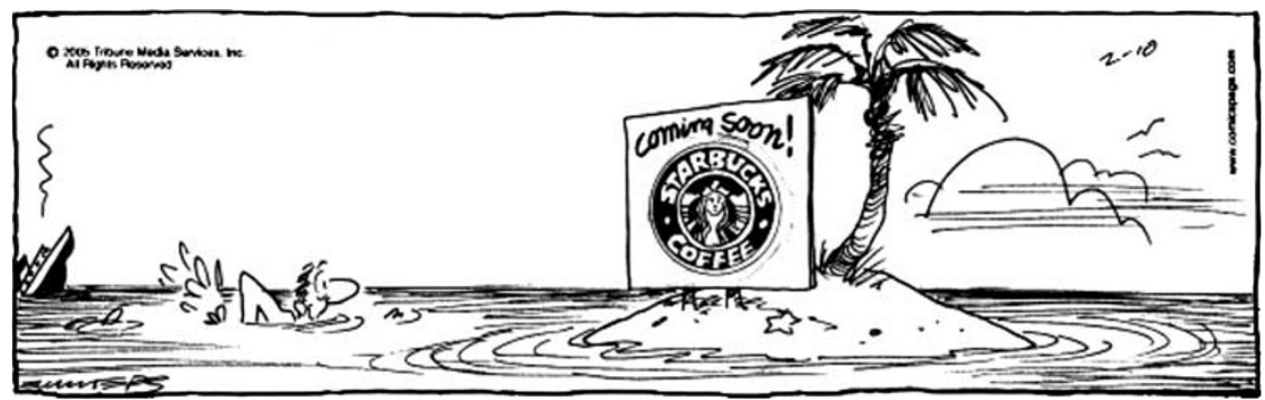

Figure 2 Examples of the visual expressiveness of symbolic haters, http://www.shinyhappyhead.com/starsucks.htm visited 20th April, 2007

like-minded consumers regarding how to sue the targeted company in similar situations. ${ }^{29}$

The quality of these types of sites is not as advanced as either experts or symbolic haters, and their expressiveness is limited to depictions of actual service failures (pictures of smashed packages, etc) or scanned and posted documents about the unresolved communications with the targeted company rather than advanced interactive website designs. The message, however, is clear, and often the examples given involve personal experiences that the reader can empathise with, and thus the reader may develop a negative opinion of the targeted company based on the experience of another person.

\section{Opportunists (low brand rank, low brand consistency)}

Opportunists rely on a company's service failures reflected in the media news as their main source of information. It can be said that opportunists are fed by media, not personal expertise nor experience, but they are trying to use flashy news stories to influence potential consumers into viewing their own website in order to increase site traffic. In other words, opportunists are generally not as personally invested as other groups of anti-brand sites. What they want is to find scandal news that maximise their visibility and attract attention on the internet.

For example, the following anti-brand site (www.ebaysucks.com) targeting ebay shows this message to newcomers:

'Is this the beginning of the end for ebay? One business writer says yes. Ebay Execs have to pay back millions due to 'spinning' lawsuit. Ebay gets hit with another suit over billing. Ebay's SquareDeal Scam! Deceives ebay users into thinking they are protected, but in fact, it's deceptive on purpose! They only pay up to $\$ 1000$ per seller, not buyer or item! Tell us what you think about this in the EbayExodus Forums! Spice Up Your Desktop-Free Download [ICON]

$73 \%$ of Tiffany items sold on ebay are fakes! So Tiffany is suing ebay.

No Doubt issues a counterfeit warning for guitars being sold on ebay as autographed by band members'.

You can download free downloads to 'spice-up your desktop', which provides a link to media news regarding the targeted brands. Also, interestingly, at the bottom of the site, the site owner posted the following information:

'All Rights Reserved, including copyrights \& trademarks, 1999-2006 EbayExodus, EbayExodus.com, EbaySucks, EbaySucks.com, 
EbaysDeadJim, EbaysDeadJim.com, F..kEbay, F..kEbay.com, TheBestAuctionList.com and the 'circle-hash' logo (meaning 'NO Ebay') are all trademarks of EbayExodus. com. All Rights Reserved.The information and articles on this website are given freely here in this context, but to use it elsewhere without compensation is stealing. Stealing is bad. It gives you headaches and your teeth fall out. Don't do it!'

Although they are not many in numbers, clearly the site owners are trying to increase website popularity and traffic through buying the rights to all possible negative domain names potentially used in the future. The above-listed alternative domain names direct traffic to one antibrand site targeting ebay, thus maximising its site traffic. Web designs are not of good quality and are less expressive, but generally focus on free downloads or products. Since the downloads offered are free, they might be protected from legal attacks as well.

\section{POSSIBLE STRATEGIES FOR HANDLING NDJ EFFECTS}

Anti-brand sites can be either harmful or beneficial to many business operations in both direct and indirect ways. Although anti-brand sites can harm a company and its brand, they can also indirectly provide opportunities and benefits for companies. Therefore, four basic strategies are offered for companies who wish to benefit from and control the aforementioned negative NDJ effects. These proposed strategies can be used to address each type of anti-brand site in different scenarios, but also suggest the most effective strategies for each specific type. In this context, the pros and cons of these four strategies will be discussed in order to reach clear and understandable consumer-centred market relationships and market welfare as framed in Table 4.
Table 4 Strategies for handling the effects of NDJ

\begin{tabular}{lll}
\hline & Brand rank & \\
\cline { 2 - 3 } Brand & High & Low \\
\hline High & $\begin{array}{l}\text { Work with } \\
\text { Experts }\end{array}$ & $\begin{array}{l}\text { Monitor } \\
\text { Symbolic Haters }\end{array}$ \\
Low & $\begin{array}{l}\text { Talk to } \\
\text { Complainers }\end{array}$ & $\begin{array}{l}\text { Combat } \\
\text { Opportunists }\end{array}$ \\
\hline
\end{tabular}

\section{Work with experts}

Experts might alert the company to problems, and expertise shared on the sites can be used in a company's market valuecreation process in the future. The feedback gained from such sites is free to the company, unlike customer-satisfaction surveys or consultants that come at a price. Some very useful information could come from sites developed by ex-employees who have extensive knowledge of the company. In some cases, these exemployees might have been unable to share their ideas while employed because of bureaucracy or other organisational barriers. Therefore, working with experts can help a company discover new ideas and learn more about their challenges and solutions as well. The questions, however, still remains 'to what extent does this hostile language and brand opposition impact your market share and brand value?' or 'how can you control and reduce this hate, and, if possible, use the information provided to your advantage?'

First, a company must analyse and determine the 'hostility level' and 'expertise level' of such sites. The trade-off between hostility and expertise can give an idea as to how much hate a company should tolerate in order to reach some level of collaboration with such sites' users. If the hostility level is extremely aggressive and the expertise will offer nothing in terms 
of value for the company, the company might need to monitor the site before the hate generated reaches harmful levels. If a company reaches a somewhat manageable level of hostility along with a good level of consumer expertise through these sites, it should, however, encourage consumer involvement in the market co-value-creation process as discussed below.

Bringing customers to the centre of the value-creation process, networking and creating open dialogue between them and the company will eventually lead to mutual satisfaction between the consumer and the company. ${ }^{31}$ As discussed earlier, such consumers analyse a whole system carefully without any distinction between consumption and production functions (ie McDonald's example in the previous section). This, in turn, helps the company to maximise complete value-creation processes on multiple levels ${ }^{32}$ as long as the targeted company can understand and control the hostility level of such sites.

\section{Monitor symbolic haters}

Symbolic haters might generally be under the influence of negative WOM in the markets. Therefore, the challenge is how the company should work on disseminating timely positive and credible information about itself to gain such consumers through focusing on possible consumers' in-groups.

The insight they may provide on their sites will likely not be as useful as that provided by experts, because symbolic haters might have a tendency to become irrational and any valid feedback they provide will also probably be provided by other sites that are less emotionally charged. Companies should closely monitor what these sites are talking about and be open to any communication form directed to consumers in order to control this symbolic (or sometimes even disingenuous) hate targeted towards their brands. In other words, a company cannot defend its perspectives without knowing the truth behind the news broadcasted by such sites.

One solution could be monitoring such hate sites and discussion boards with the help of professional companies who do this in order to combat what is said about them on the internet (ie CyberAlert). Such companies conduct media monitoring to help clients fend off possible damage by conducting more than 2,000 ongoing daily searches of corporate and brand names for public relations, reputation management, competitive intelligence, market intelligence and market research, and trademark infringement. ${ }^{33}$ Here is an example depicted by an internet monitoring company's success stories section:

'Case in Point: A major manufacturer became the focal point for activists' crusades against genetically-modified foods.

Action:The company positioned itself to 'own' the issue so that public debate on the Internet takes place largely on the company's terms' ${ }^{33}$

Other monitoring companies (ie Delahaye) also develop reputation indices to track down a company's reputation in the markets and to provide the basis for understanding and improving its reputation positioning. ${ }^{34}$ This kind of constant monitoring effort might give a company the chance to intercept targeted hate towards them to develop simultaneous counter-strategies accordingly.

From a marketing point of view, online brand communities can be a good starting point to build a communication platform to understand problems and encourage symbolic haters to interact with the company and with satisfied consumers in 
order to develop new identities (specifically new brand identities) and solutions that they can be comfortable with. Online communities might also reduce customer services costs by providing customerto-customer solution interactions. ${ }^{6}$ Importantly, WOM created in online communities may have higher credibility than marketer-generated messages on the internet. ${ }^{35}$ In this context, online brand communities may give a company the chance to be involved in discussions in such digital spaces and to some extent may give the company a chance to control negative WOM before it is disseminated to markets and becomes harmful.

\section{Talk to complainers}

These are the consumers that might have been satisfied with a company's products and services for a while, but have grown dissatisfied.They are likely still looking for the spark or enjoyment they once felt when they met with that brand. Since such sites are trying to get attention and are focusing on major service failure scandals, companies should contact site owners to solve such consumer dissatisfaction problems before the aggression begins to impact the company's brand identity on the internet. This, in turn, necessitates a closer analysis of the reasons behind the complaints, thus an effective consumer services management especially when consumers first contact the company with a problem.

Because negative WOM spreads quickly and may be found online indefinitely, ${ }^{36}$ companies should attempt to transform the negative WOM to positive WOM and improve the experience of their consumers. Although such site owners can go to online discussion groups and/or online third-party forums (eg epinions.com), which can be detrimental to the company if these complaints are detected early, a company may be able to benefit from these complaints. ${ }^{37}$ Companies should take advantage of this opportunity to develop a stronger relationship with their customers. An effective complaint system with an option of personalised services might give a company the ability to understand their consumers better. Such complaint systems would be a good way to start clear communication with complainers by creating a company's own effective online response and feedback system on its own website. And, publicity of such system can even attract new consumers.

Companies could also check e-complaint sites and consumer blogs to monitor new problems and to make sure whether the complained of event is a one-time occurrence or a common problem. When it is appropriate, companies can send emails to upset customers, perhaps attaching discount coupons or gift cards to show its sincerity. Some corporations might choose to ignore such sites, believing that providing a response might attract more publicity to the issue. But quietly and regularly monitoring such anti-brand sites then tells how much they are doing well. In this way, companies are given the chance to develop their products and services, and finally to provide an opportunity to stop such sites' negative speech before negative WOM is disseminated to the whole market. Either way, companies must keep one ear open for extreme critiques and bias-driven broadcasting. In many business environments, especially in this digital age, talking to consumers might be less costly and more rewarding than putting a brand at risk.

\section{Combat opportunists}

Such sites are looking for an opportunity to be recognised and reach a level of 
awareness that can be realised by the public. They can be very harmful once they find scandalous events regarding a targeted brand, which brings the site higher visibility and traffic. Opportunists are trying to steal web traffic from the targeted company, and will search the media to find anything they can use to gain attention by attacking brands. In a pre-emptive attempt to prevent the creation of such anti-brand sites, corporations can buy potential negative domain names that can be targeted on the internet (egVolvo's volvosucks.com, Chase Manhattan's chasesucks.com, ihatechase.com and Exxon's exxonsucks.com). ${ }^{38-40}$ Priceline. com purchased pricelinesucks.com even before priceline.com went online. ${ }^{40,41}$

If opportunist hate sites survive and thrive, it is possible that they could morph into complainers or symbolic haters, which should motivate companies to monitor them carefully and take action (either legal or counter-marketing actions) when necessary. Companies should be aware/cautious of opportunists' existence on the internet and ready to combat them to stop brand erosion and web trafficbecause they do not bring benefit or value creation to a company. Companies might need to re-evaluate search engine marketing efforts (ie keyword selection and link popularity determination etc) by taking into consideration such sites. Otherwise, the company may end up needing to buy the anti-brand site in order to shut it down ${ }^{5}$ or face a new addition to its list of hated anti-brand sites.

\section{CONCLUSION}

Anti-brand hate sites are becoming a threat to companies and sometimes may function like market agents, but can also be sources of valuable information for a company if monitored, understood and managed well. The majority of companies might be choosing to ignore these sites while others are spending money developing websites or filing lawsuits to combat them. Companies need to realise that these sites can direct extreme criticism to companies and bias-driven broadcasting to markets and consumers. Whether they are 'experts' or 'opportunists', companies need to understand and analyse such sites' language, culture and function in order to determine how to direct the hate generated by such sites into a more productive and positive form of communication that helps to maximise both company and consumer benefit in markets.

\section{Acknowledgments}

I appreciate Sandeep Krishnamurthy's helpful comments and support during this study.

\section{References}

(1) Ehrenberg, A., Goodhardt, G. J. and Barwise, P. T. (1990) 'Double jeopardy revisited', Journal of Marketing, Vol. 54, No. 3, pp. 82-91.

(2) Uncles, M., Ehrenberg, A. and Hammond, K. (1995) 'Patterns of buyer behavior: Regularities, models, and extensions', Marketing Science, Vol. 14, No. 3, pp. G71-G79.

(3) Ah, K. K. and Ehrenberg, A. (1984) 'Patterns of store choice', Journal of Marketing Research, Vol. 21, No. 4, pp. 399-401.

(4) Donthu, N. and Hershberger, E. (2001) 'Double jeopardy in internet site choice', Quarterly Journal of Electronic Commerce, Vol. 2, No. 3, pp. 199-204.

(5) See www.mi2g.net/cgi/mi2g/frameset.php?pageid= http $\% 3 \mathrm{~A} / /$ www.mi2g.net/cgi/mi2g/press/ 021204.php.

(6) Kucuk, S. U. and Krishnamurthy, S. (2007) 'An analysis of consumer power on the internet', Technovation, Vol. 27, No. 1/2, pp. 47-56.

(7) Stewart, D. W. and Pavlou, P (2002) 'From consumer response to active consumer: Measuring the effectiveness of interactive media', Journal of the Academy of Marketing Science, Vol. 30, No. 4, pp. 379-396.

(8) Wolrich, C. Top Corporate Hate Web Sites', Forbes.com, Available at http://www.forbes.com/ home/commerce/2005/03/07/cx_cw_0308hate. html. 
(9) TMI, Inc, $v$ Maxwell. 2004. 368 F.3d 433 (5th Cir.).

(10) Lucas Nurcery \& Landscaping, Inc. $v$ Grosse. 2004. 359 F.3d 806 (6th Cir.).

(11) See http://www.pub.umich.edu/daily/1998/oct/ 10-14-98/news/news11.html.

(12) See http://bwnt.businessweek.com/brand/2005/ index.asp.

(13) Kucuk, S. U. (2002) 'Changing consumerism with the internet: A global perspective', Journal of Euromarketing, Vol. 12, No. 1, pp. 41-62.

(14) Fournier, S. (1998) 'Consumers and their brands: Developing relationship theory in consumer research', Journal of Consumer Research, Vol. 24, No. 4, pp. 343-373.

(15) Hirschman, A. (1970) 'Exit, Voice and Loyalty', Harvard University Press, Cambridge, MA.

(16) Kozinets, R. (2002) 'Can consumers escape the market? Emancipatory illuminations from burning man', Journal of Consumer Research, Vol. 29, No. 1, pp. 20-38.

(17) Firat, F. and Venkatesh, A. (1995) 'Liberatory postmodernism and the reenchantment of consumption', Journal of Consumer Research, Vol. 22, No. 3, pp. 239-267.

(18) Kozinets, R. and Handelman, J. (2004) 'Adversaries of consumption: Consumer movements, activism, and ideology', Journal of Consumer Research, Vol. 31, No. 3, pp. 691-704.

(19) See http://www.rajuabju.com/literature/antimcdonalds.htm.

(20) See http://www.vanwensveen.nl/rants/microsoft/ IhateMS_5.html.

(21) See http://www.msboycott.com/.

(22) See http://www.geocities.com/\%7Ejmgould/ disney.html.

(23) See http://www.jamesshuggins.com/h/tek1/ amazon_dot_com_and_web_patents.htm.

(24) See http://www.gnu.org/philosophy/amazon. html.

(25) See http://www.ihatestarbucks.com/why.php.

(26) See http://www.eskimo.com/ webguy/writings/ upssucks.html.

(27) See http://www.reverendcolin.com/UPSSucks.html.
(28) See http://www.rossde.com/UPS_sucks.

(29) See http://www.trixiepixgraphics.com/bad_ businesses/UPS/ups_sucks.htm.

(30) See www.innercitypress.org/citi.html.

(31) Oliver, R. L. (2006) 'Co-producers and coparticipants in the satisfaction process: Mutually satisfying consumption', in Lusch Robert, F. and Vargo Stephen, L. (eds.) 'The Service-Dominant Logic of Marketing: Dialog, Debate, and Directions', ME Sharpe, Armonk, NY, pp. 118-127.

(32) Etgar, M. (2006) 'Co-production of services: A managerial extension', in Lusch Robert, $F$. and Vargo Stephen, L. (eds.) 'The Service-Dominant Logic of Marketing: Dialog, Debate, and Directions', ME Sharpe, Armonk, NY, pp. 128-138.

(33) See http://www.cyberalert.com/success.html.

(34) See http://www.delahaye.com/corporate-reputationmeasurement.asp.

(35) Bickart, B. and Schindler, R. M. (2001) 'Internet forums as influential sources of consumer information', Journal of Interactive Marketing, Vol. 15, No. 3, pp. 31-40.

(36) Goetzinger, L., Park, J. K. and Widdows, R. (2006) 'E-customers' third party complaining and complimenting behaviour', International Journal of Service Industry Management, Vol. 17, No. 2, pp. 193-206.

(37) Bitner, M. J., Brown, S. W. and Meuter, M. L. (2000) 'Technology infusion in service encounters', Journal of the Academy of Marketing Science, Vol. 28, No. 1, pp. 138-149.

(38) Fitzgerald, K. (2000) 'New domain suffixes rich for profiteers', Advertising Age, Vol. 71, No. 51, pp. 58-60.

(39) Nemes, J. (2000) 'Domain names have brand impact', B to B Chicago, Vol. 85, No. 12, pp. 20.

(40) Harrison-Walker, J. L. (2001) 'E-complaining: A content analysis of an internet complaint forum', Journal of Services Marketing, Vol. 15, No. 5, pp. 397-412.

(41) Marlatt, A. (1998) 'Who's the owner of chasesucks.com and chasestinks? Three guesses', Internet World 1998, formerly Web Week, http://iw.com/ print/1998/15/in.../19980615-antidomains.htm. 